\title{
Cardiorespiratory fitness in long-term lymphoma survivors after high-dose chemotherapy with autologous stem cell transplantation
}

Jo S Stenehjem ${ }^{\star 1,2}$, Knut B Smeland ${ }^{1,9}$, Klaus Murbraech ${ }^{3,9}$, Harald Holte ${ }^{4}$, Stein Kvaløy ${ }^{1,5}$, Lene Thorsen ${ }^{1}$, Ingerid Arbo ${ }^{6}$, Lee W Jones ${ }^{7}$, Svend Aakhus ${ }^{3,6}$, May Brit Lund ${ }^{8,10}$ and Cecilie E Kiserud ${ }^{1,10}$

${ }^{1}$ National Resource Center for Late Effects after Cancer Treatment, Department of Oncology, Oslo University Hospital, Oslo 0424, Norway; ${ }^{2}$ Department of Research, Cancer Registry of Norway, Oslo 0304, Norway; ${ }^{3}$ Department of Cardiology, Oslo University Hospital, Oslo 0424, Norway; ${ }^{4}$ Department of Oncology, Oslo University Hospital, Oslo 0424, Norway; ${ }^{5}$ Faculty of Medicine, University of Oslo, Oslo 0316, Norway; ${ }^{6}$ Department of Circulation and Medical Imaging, NTNU, Trondheim 7491, Norway; ${ }^{7}$ Department of Medicine, Memorial Sloan Kettering Cancer Center, New York City, NY 10065, USA and ${ }^{8}$ Department of Respiratory Medicine, Oslo University Hospital, Oslo 0424, Norway

Background: Cardiorespiratory fitness as measured by peak oxygen consumption $\left(\mathrm{VO}_{2 p e a k}\right)$ is a strong predictor of longevity and may be compromised by anticancer therapy, inactivity, and smoking. We compared $\mathrm{VO}_{2 p e a k}$ among lymphoma survivors (LSs) with reference data from healthy sedentary subjects, after a 10.2-year (mean) follow-up post high-dose chemotherapy with autologous stem cell transplantation (HDT-ASCT). We further examined the association between $\mathrm{VO}_{2 p e a k}$ and treatment, physical activity, smoking, pulmonary, and cardiac function.

Methods: Lymphoma survivors treated with HDT-ASCT in Norway 1987-2008 were eligible. VO 2 peak was assessed by cardiopulmonary exercise testing. Pulmonary function testing and echocardiography were also conducted. Data on treatment, physical activity, and smoking were collected from hospital records and questionnaires. $\mathrm{VO}_{2 p e a k}$ was compared with age-sex predicted reference data. Linear regression was used to associate clinical factors with $\mathrm{VO}_{2 p e a k}$ cross-sectionally.

Results: A total of 194 LSs without heart failure were studied. Mean VO2peak was $4.5 \%$ and $7.7 \%$ below norms in females and males, respectively. Twenty-two percent had impaired ( $<80 \%$ predicted) $\mathrm{VO}_{2 \text { peak. }}$ Decreasing $\mathrm{VO}_{2 \text { peak }}$ was associated with impaired diffusion capacity and current smoking, while physical activity level and $\mathrm{VO}_{2 p e a k}$ were positively associated.

Conclusion: We suggest increased attention towards physical activity counseling and smoking cessation advice to preserve cardiorespiratory fitness in LSs after HDT-ASCT. Patients with impaired diffusion capacity may benefit from subsequent monitoring to detect pulmonary vascular diseases.

High-dose chemotherapy with autologous stem cell transplantation (HDT-ASCT) has been a treatment option for Hodgkin (HL) and non-Hodgkin lymphomas (NHL) since the mid-1980 (Linch et al,
1993; Schmitz et al, 2002). The number of lymphoma survivors (LSs) post HDT-ASCT has been steadily growing as treatment regimens and indications have evolved (Schmitz et al, 1996).

*Correspondence: Dr JS Stenehjem; E-mail: jo.stenehjem@kreftregisteret.no

${ }^{9}$ These authors share co-second authorship.

${ }^{10}$ These authors share co-senior authorship.

Received 28 January 2016; revised 4 April 2016; accepted 16 May 2016; published online 28 June 2016

(c) 2016 Cancer Research UK. All rights reserved 0007-0920/16 
In recent years, significant improvements in 5-year survival have been reported for patients receiving this therapy ranging $59-73 \%$ for HL and up to $62 \%$ for NHL (Vanderwalde et al, 2013; Smeland et al, 2013a, 2015).

As survival continues to improve, the proportion of LSs with treatment-related late effects increases (Bhatia et al, 2005), and the role of effective countermeasures is becoming increasingly important. The last decade, lifestyle change after cancer has received increased attention, and physical activity and smoking cessation have been highlighted as modifiable factors that may improve the length and quality of life among cancer survivors (Demark-Wahnefried et al, 2005). Recently, high cardiorespiratory fitness in male cancer survivors was associated with a one-third risk reduction of cancer mortality, compared with those with low cardiorespiratory fitness (Lakoski et al, 2015).

Cancer therapy may cause damage to organs involved in the transport or use of oxygen, and cardiac and pulmonary late effects related to pre HDT-ASCT therapies such as doxorubicin, bleomycin, and mediastinal irradiation are well known (Lund et al, 1996a, b; Murbraech et al, 2015). Such treatment-induced impairments, together with physical inactivity, might reduce cardiorespiratory fitness considerably in cancer survivors (Jones et al, 2009; Lakoski et al, 2012). Measurement of peak oxygen uptake $\left(\mathrm{VO}_{2 \text { peak }}\right)$ by cardiopulmonary exercise testing represents the gold standard assessment of cardiorespiratory fitness, and is useful to assess the global effect of these impairments on cardiorespiratory fitness (Jones et al, 2008). Further, reduced cardiorespiratory fitness is a strong and inversely related predictor of adverse cardiovascular events in LSs (Adams et al, 2004; Jones et $a l, 2014)$. Therefore, preserving cardiorespiratory fitness by physical activity might be life-prolonging in intensively treated cancer survivors.

The present study is, to our knowledge, the first to systematically address cardiorespiratory fitness among long-term LSs after HDT-ASCT. Our primary aim was to compare $\mathrm{VO}_{2 \text { peak }}$ with data from a healthy, sedentary reference population. Second, we examined $\mathrm{VO}_{\text {2peak }}$ according to treatment, physical activity, smoking, pulmonary impairment, cardiac function, and haemoglobin level among the LSs.

\section{MATERIALS AND METHODS}

Study population. The study population was recruited from all HL and NHL survivors treated with HDT-ASCT in Norway between 1987 and 2008 (Smeland et al, 2013b). A total of 399 LSs aged 18 years or older at HDT-ASCT, who were resident in Norway by March 2012, and not currently undergoing active treatment for relapsed disease, were eligible and invited to participate. After an average follow-up of 10.2 (range 3-25) years since HDT-ASCT, the participants were asked to attend an outpatient visit between March 2012 and March 2014, which included a symptom-limited cardiopulmonary exercise test, a pulmonary function test, echocardiography, blood sampling, and a questionnaire. The participants were recruited from Oslo University Hospital (OUH) $(n=159)$ and St Olavs University Hospital (Trondheim) $(n=35)$.

The study was approved by the South East Regional Committee for Medical and Health Research Ethics. Written informed consent was obtained from all participants.

Treatment. Treatment data were collected from medical records and databases at OUH and St Olavs University Hospital. The total number of treatment lines of chemotherapy given before HDTASCT was registered (1, 2, or $\geqslant 3$ ). During 1987-1995, total body irradiation (TBI, 1.3 Gy twice daily for 5 consecutive days with lung shielding for two doses) followed by high-dose cyclophosphamide
( $60 \mathrm{mg} \mathrm{kg}^{-1}$ for 2 days) constituted the high-dose regimen. From 1995 onwards, the conditioning regimen was constrained to chemotherapy only, including carmustine, etoposide, cytarabine, and melphalan (BEAM). Cumulative doses of chest radiotherapy (RT) and chemotherapy were calculated and divided into categories: chest RT (unexposed, 1-13 Gy, > 13-65 Gy), doxorubicin ( $<300 \mathrm{mg} \mathrm{m}^{-2}, 300-399 \mathrm{mg} \mathrm{m}^{-2}, 400-775 \mathrm{mg} \mathrm{m}^{-2}$ ), cyclophosphamide $\left(0-3.49 \mathrm{~g} \mathrm{~m}^{-2}, 3.50-5.99 \mathrm{~g} \mathrm{~m}^{-2}, 6.00-12.30 \mathrm{~g} \mathrm{~m}^{-2}\right)$, and bleomycin (unexposed, $1-12$ international units (IU) $10^{4} / \mathrm{m}^{2}$, $\left.>12-21 \mathrm{IU} \cdot 10^{4} / \mathrm{m}^{2}\right)$. Daunorubicin doses were converted to doxorubicin isotoxic doses using a conversion factor of 0.83 (Fulbright, 2011).

Symptom-limited cardiopulmonary exercise testing. Cardiopulmonary exercise testing and pulmonary function tests were performed on a SensorMedics Vmax unit (VIASYS Respiratory Care Inc., Yorba Linda, CA, USA) with an Ergoline 800 bicycle (Bitz, Germany). Patients recruited from Trondheim were exercise tested on a Jaeger Oxycon Pro unit (VIASYS Healthcare GmbH, Hochburg, Germany) coupled with a Monark Ergomedic 839E bicycle (Monark Exercise AB, Vansbro, Sweden). The gas exchange units were calibrated daily. During exercise testing, 12-lead electrocardiography, gas exchange, and ventilatory variables were monitored continuously, and testing was continued until exhaustion (respiratory exchange ratio (RER) $>1.10$ ). The test consisted of three phases: a 2-minute warm-up (20-50 Watt workload), an incremental exercise phase of $8-12$ min until exhaustion, and 2-min recovery (American Thoracic Society; American College of Chest Physicians, 2003). $\mathrm{VO}_{2 \text { peak }}$ was the primary outcome and was recorded together with peak oxygen pulse, maximum ventilation, maximum workload, RER, and perceived exertion (Borg scale). Following the procedure of Jones et al (2010), percent-predicted $\mathrm{VO}_{2 \text { peak }}$ was calculated by dividing the measured values of our patients by those derived from age-sex dependent regression equations of $\mathrm{VO}_{2 \text { peak }}$ from a healthy sedentary population (Fitzgerald et al, 1997; Wilson and Tanaka, 2000). Impaired $\mathrm{VO}_{2 \text { peak }}$ was defined using the percent-predicted scale to account for sex-age difference, and set to $<80 \%$ of predicted. Height and weight were measured, and body mass index (BMI) was calculated as $\mathrm{kg} \mathrm{m}^{-2}$.

Pulmonary function. Pulmonary function tests included dynamic spirometry, determination of static lung volumes, and gas diffusion capacity (Macintyre et al, 2005; Miller et al, 2005; Wanger et al, 2005). Recorded spirometric variables were forced vital capacity (FVC), forced expiratory volume in $1 \mathrm{~s}\left(\mathrm{FEV}_{1}\right)$, and $\mathrm{FEV}_{1} / \mathrm{FVC}$. Static lung volume was recorded as total lung capacity (TLC). Gas diffusion was expressed by the transfer factor of the lungs for carbon monoxide (DLCO). Percentages of predicted normal lung function values were calculated based on the reference values recommended by the ERS (Quanjer et al, 1993). Pulmonary function was dichotomised according to obstructive impairment $\left(\mathrm{FEV}_{1}<80 \%\right.$ of predicted and $\left.\mathrm{FEV}_{1} / \mathrm{FVC}<0.7\right)$, restrictive impairment (TLC and FVC $<80 \%$ of predicted, for 8 patients TLC data were missing and only FVC data were used to define restrictive impairment), and diffusion capacity impairment (DLCO $<80 \%$ of predicted). These cutpoints correspond to the lower 5 th percentiles in the reference material recommended by the ERS.

Echocardiography. Left ventricular ejection fraction (LVEF) was assessed by Simpson's biplane rule (Lang et al, 2005), and left ventricular systolic dysfunction (LVSD) was defined as a LVEF of $<50 \%$ (Davies et al, 2001). Patients with heart failure ((HF), defined as current or prior symptoms according to Hunt et al, (2009)) were excluded to more clearly elucidate the influence of other factors than cardiac output on $\mathrm{VO}_{2 \text { peak }}$ (Basset and Howley, 2000). The echocardiographic examination has been described in detail elsewhere (Murbraech et al, 2015). 
Blood sampling. Blood samples were collected at $0800 \mathrm{~h}$, and analysed for haemoglobin $(\mathrm{Hb})$ level among other parameters. Anaemia was defined as $\mathrm{Hb}$ levels $<11.7 \mathrm{~g} \mathrm{dl}^{-1}$ (women) and $<13.4 \mathrm{~g} \mathrm{dl}^{-1}$ (men) (Rodgers et al, 2008).

Questionnaire. Self-reported physical activity was recorded as frequency (never, <1/week, 1/week, 2-3/week, almost daily), intensity (low, moderate, vigorous), and duration ( $<15 \mathrm{~min}$, 15-29 $\mathrm{min}, 30 \mathrm{~min}-1 \mathrm{~h},>1 \mathrm{~h}$ ), and has been validated previously (Kurtze et al, 2008). Minutes per week of physical activity (0-100, $101-180,181-375)$ was calculated as a product of the frequency and duration variables. A summary score, reflecting overall physical activity level, was calculated by the following equation: $($ frequency/5) $+($ intensity/3) $+($ duration/4), yielding an ordinal variable (range 1.18-3.00) that was categorised into three equally sized thirds (low, medium, high), where inactive patients were placed in the low physical activity group (Nilsen et al, 2008). According to the World Health Organization (WHO) guidelines on physical activity, those who reported $\geqslant 150$ min week $^{-1}$ of moderate intensity or $\geqslant 75 \mathrm{~min}^{-1 e e k^{-1}}$ of vigorous intensity was categorised as 'meeting guidelines' and the rest as 'not meeting guidelines'. Smoking status was recorded as 'never', 'former', or 'current'.

Statistical analysis. Data are presented as mean \pm s.d., median (ranges), or numbers (\%). Paired and independent samples $t$-tests were used for mean comparisons of normally distributed data, the Wilcoxon rank-sum test was used to compare ordinal data, and the Chi-square test was used to compare categorical data. Linear regression was used to estimate regression coefficients (RCs) with corresponding 95\% confidence intervals (CIs) and $P$-values. $\mathrm{VO}_{2 \text { peak, }}$ maximum ventilation, and maximum workload were examined in uni- and multivariable regression models according to relevant explanatory variables (specified in Table 3 and Supplementary Table S1, and Figure 3). After performing linear regression, the post-estimation command 'margins' of Stata 14 was used as described by Mitchell (2012) to derive adjusted means of $\mathrm{VO}_{2 \text { peak }}$ according to physical activity level across categories of cumulative doxorubicin, adjusted for gender, age at examination, BMI, smoking, and diffusion capacity.

Tests for significance were two-sided and $P$-values of $\leqslant 0.05$ were considered as statistically significant. Variables with $P \leqslant 0.05$ in the univariable models or that were considered clinically relevant were included in the multivariable models. Tests for trend across categories were performed by entering categorical variables as continuous variables in the models. Data analyses were performed using Stata version 14 (StataCorp, College Station, TX, USA).

\section{RESULTS}

A total of 194 survivors of HL (21\%) and NHL (79\%), who completed exercise, pulmonary function, and echocardiographic testing, were included in the present analysis (Figure 1). Primary diagnosis, gender, age at survey, time from HDT-ASCT to survey, chest RT, and chemotherapy (cyclophosphamide and doxorubicin) did not differ between participants and non-participants (results not shown). Among the participants, mean age at examination was 55 years, two-thirds were men, $17 \%$ reported current smoking, and $47 \%$ met the WHO recommendation on physical activity. In women and men, $\mathrm{VO}_{2 \text { peak }}$ averaged 23.5 and $29.7 \mathrm{ml} \mathrm{kg}^{-1}$ min ${ }^{-1}$, respectively, and was impaired in $20 \%$ and $23 \%$ (Table 1 ).

$\mathrm{VO}_{2 \text { peak }}$ in LSs after HDT-ASCT compared with the reference population. Among female participants, the percent-predicted (PP) $\mathrm{VO}_{2 \text { peak }}$ averaged 95.5 (95\% CI, 90.5-100.5), whereas that for
728 lymphoma survivors

$>18$ years treated with

HDT-ASCT 1987-2008
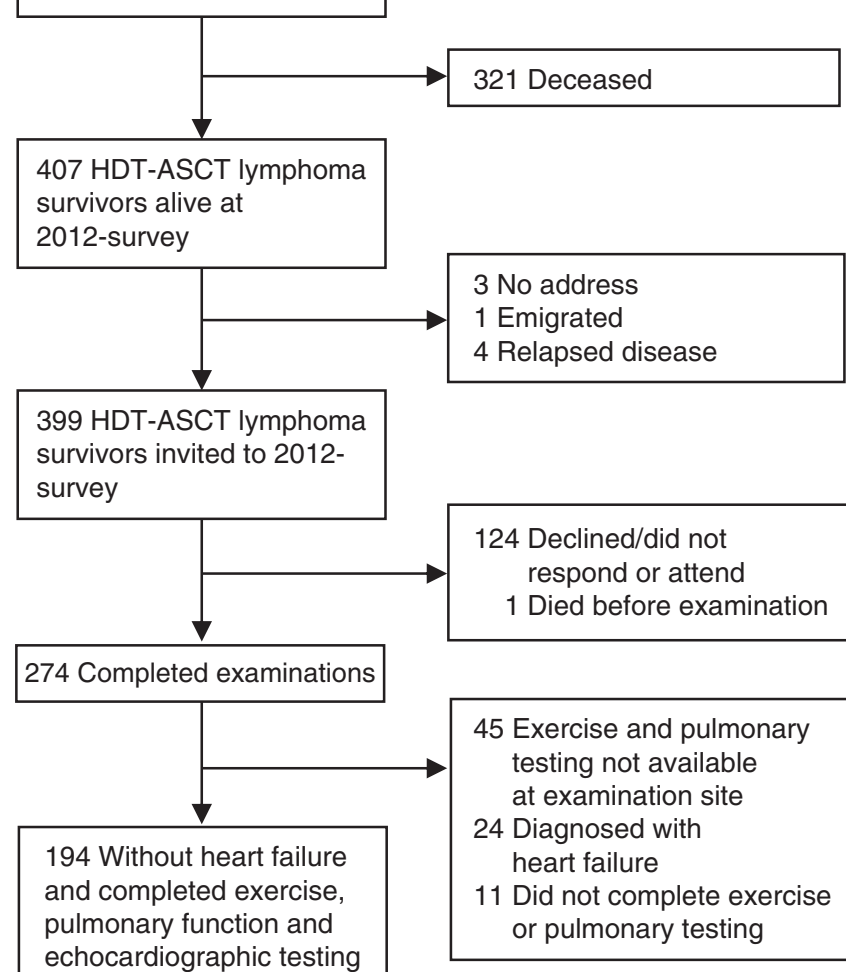

Figure 1. Overview of study design and exclusions.

males (PP 92.3, 95\% CI 89.0-95.6) was significantly lower than the reference population (Figure 2 ).

When $\mathrm{VO}_{2 \text { peak }}$ was examined by level of physical activity, both the external comparison with the reference population (Figure 2) and the internal comparison (quartiles of $\mathrm{VO}_{2 \text { peak, }}$, Table 2) were increasing in a dose-dependent manner. The low active LSs had significantly lower $\mathrm{VO}_{2 \text { peak }}$ (females: PP 87.5, 95\% CI 78.8-96.3; males PP 85.8, 95\% CI 82.0-89.7) than the reference population, while the $\mathrm{VO}_{2 \text { peak }}$ values of those who reported high activity did not differ significantly from the reference population (females: PP 105.6, 95\% CI 94.8-116.5; males: PP 100.9, 95\% CI 94.0-107.8) (Figure 2). For all physical activity measures, except intensity, there was a significant correlation with $\mathrm{VO}_{2 \text { peak }}$ expressed as impaired $v s$ normal (Table 2).

Factors associated with $\mathrm{VO}_{2 \text { peak, }}$ ventilation, and workload. Table 3 shows uni- and multivariable models of factors associated with $\mathrm{VO}_{2 \text { peak }}$, maximum ventilation, and maximum workload. In the multivariable analysis, all outcomes were positively associated with an increase in physical activity level $\left(P_{\text {trend }}<0.01\right)$. Current smoking $(\mathrm{RC}-2.07, P=0.05)$ and impaired diffusion capacity $(\mathrm{RC}-2.33, P<0.01)$ were significantly associated with a decrease in $\mathrm{VO}_{2 \text { peak. }}$ A reduction in maximum ventilation was associated with a cumulative bleomycin dose of $>12-21 \mathrm{IU} \cdot 10^{4} / \mathrm{m}^{2}$ (RC $-13.9, P=0.05$, compared with the unexposed) and obstructive pulmonary impairment $(\mathrm{RC}-14.3, P<0.01)$. Maximum workload was positively associated with an increase in $\mathrm{VO}_{2 \text { peak }}(\mathrm{RC}$ 58.5, $P<0.01)$ and inversely associated with impaired diffusion capacity (RC $-7.2, P=0.03$ ). No association with chest RT was found for any of the outcomes.

Physical activity level, doxorubicin exposure, and $\mathrm{VO}_{2 \text { peak }}$. Stratified on physical activity level, an increasing doxorubicin 
Table 1. Participant characteristics at time of examination by gender

\begin{tabular}{|c|c|c|c|}
\hline Variables & Total & \multicolumn{2}{|c|}{ Gender } \\
\hline Participants, $N(\%)$ & $194(100)$ & $69(36)$ & $125(64)$ \\
\hline Age at examination, mean years (s.d.) & $55(12)$ & $54(14)$ & $54(11)$ \\
\hline Time (years) since primary lymphoma diagnosis, mean (s.d.) & $12.9(6.6)$ & $12.5(6.1)$ & $13.1(6.8)$ \\
\hline $\begin{array}{l}\text { Smoking, } N(\%) \\
\text { Never } \\
\text { Former } \\
\text { Current }\end{array}$ & $\begin{array}{l}77(40) \\
83(43) \\
34(17) \\
\end{array}$ & $\begin{array}{l}28(41) \\
27(39) \\
14(20) \\
\end{array}$ & $\begin{array}{l}49(39) \\
56(45) \\
29(16) \\
\end{array}$ \\
\hline $\begin{array}{l}\text { Lymphoma subtypes, } N(\%) \\
\text { Hodgkin lymphoma (HL) } \\
\text { Non-Hodgkin lymphoma (NHL) }\end{array}$ & $\begin{array}{r}40(21) \\
154(79) \\
\end{array}$ & $\begin{array}{l}16(23) \\
53(77)\end{array}$ & $\begin{array}{r}24(19) \\
101(81) \\
\end{array}$ \\
\hline $\begin{array}{l}\text { Type of HDT-ASCT, } N(\%) \\
\text { TBI + high-dose cyclophosphamide } \\
\text { BEAM treatment }\end{array}$ & $\begin{array}{r}33(17) \\
161(83) \\
\end{array}$ & $\begin{array}{l}11(16) \\
58(84)\end{array}$ & $\begin{array}{r}22(18) \\
103(82) \\
\end{array}$ \\
\hline Relapse post HDT-ASCT, $N(\%)$ & $40(21)$ & $10(14)$ & $30(24)$ \\
\hline RIC allogeneic SCT post HDT-ASCT, N (\%) & $14(7)$ & $4(6)$ & $10(8)$ \\
\hline Chest-RT incl. TBI, mean Gy among exposed (s.d.) & $25.2(12.2)$ & $25.3(12.2)$ & $25.1(11.8)$ \\
\hline Chest-RT excl. TBI, mean Gy among exposed (s.d.) & $34.4(7.9)$ & $33.8(10.4)$ & $34.8(6.0)$ \\
\hline Doxorubicin, mean $\mathrm{mg} \mathrm{m}^{-2}$ (s.d.) & $320(114)$ & $326(101)$ & $317(121)$ \\
\hline Cyclophosphamide, mean $\mathrm{g} \mathrm{m}^{-2}$ (s.d.) & $4.6(2.8)$ & $4.3(2.9)$ & $4.7(2.8)$ \\
\hline \multicolumn{4}{|l|}{ Exercise behaviour $(N=191)$} \\
\hline $\begin{array}{l}\text { Minutes per week, } N(\%) \\
0-100 \\
101-180 \\
181-375 \\
\end{array}$ & $\begin{array}{l}53(27) \\
72(37) \\
66(34) \\
\end{array}$ & $\begin{array}{l}18(26) \\
29(42) \\
22(32)\end{array}$ & $\begin{array}{l}35(28) \\
43(34) \\
44(35)\end{array}$ \\
\hline $\begin{array}{l}\text { Intensity, } N(\%) \\
\text { Low } \\
\text { Moderate } \\
\text { Vigorous }\end{array}$ & $\begin{array}{l}85(44) \\
90(46) \\
16(8)\end{array}$ & $\begin{array}{c}31(45) \\
34(49) \\
4(6)\end{array}$ & $\begin{array}{l}54(43) \\
56(45) \\
12(10)\end{array}$ \\
\hline $\begin{array}{l}\text { Summary score, } N(\%)^{\text {a }} \\
\text { Low } \\
\text { Medium } \\
\text { High }\end{array}$ & $\begin{array}{l}81(42) \\
53(27) \\
57(29)\end{array}$ & $\begin{array}{l}25(36) \\
27(39) \\
17(25)\end{array}$ & $\begin{array}{l}56(45) \\
26(21) \\
40(32)\end{array}$ \\
\hline WHO physical activity recommendation met, $N(\%)^{\mathbf{b}}$ & $89(47)$ & $35(51)$ & $54(44)$ \\
\hline \multicolumn{4}{|l|}{ Pulmonary function } \\
\hline $\begin{array}{l}F E V_{1} \text {, mean } \mathrm{L} \text { (s.d.) } \\
\mathrm{FVC} \text {, mean } \mathrm{L} \text { (s.d.) } \\
\mathrm{FEV} / \mathrm{FVC} \text {, mean ratio-value (s.d.) } \\
\mathrm{TLC}(\mathrm{N}=186) \text {, mean } \mathrm{L} \text { (s.d.) } \\
\mathrm{DLCO} \text {, mean mmol } \mathrm{kPa}^{-1} \mathrm{~min}^{-1} \text { (s.d.) } \\
\text { Obstructive pulmonary function, } \mathrm{N}(\%) \\
\text { Restrictive pulmonary function, } \mathrm{N}(\%) \\
\text { Impaired gas diffusion capacity, } \mathrm{N}(\%)\end{array}$ & $\begin{array}{l}3.03(0.80) \\
3.98(1.02) \\
0.76(0.07) \\
6.40(1.59) \\
7.88(2.07) \\
16(8) \\
12(6) \\
85(44)\end{array}$ & $\begin{array}{l}2.37(0.50) \\
3.06(0.60) \\
0.77(0.07) \\
5.27(1.00) \\
6.32(1.28) \\
6(9) \\
3(4) \\
36(52)\end{array}$ & $\begin{array}{l}3.40(0.69) \\
4.49(0.83) \\
0.76(0.07) \\
7.05(1.50) \\
8.74(1.94) \\
10(8) \\
9(7) \\
49(39)\end{array}$ \\
\hline
\end{tabular}




\section{Table 1. (Continued)}

\begin{tabular}{|c|c|c|c|}
\hline \multicolumn{4}{|c|}{ Gender } \\
\hline Variables & Total & Females & Males \\
\hline \multicolumn{4}{|l|}{ Cardiac function $(N=192)$} \\
\hline \multicolumn{4}{|l|}{ Blood sample $(N=193)$} \\
\hline $\begin{array}{l}\text { Haemoglobin, mean } \mathrm{g} \mathrm{dl}^{-1} \text { (s.d.) } \\
\text { Anaemia, } N(\%)\end{array}$ & $\begin{array}{r}14.0(1.2) \\
20(10)\end{array}$ & $\begin{array}{c}13.2(0.9) \\
4(6)\end{array}$ & $\begin{array}{r}14.5(1.1) \\
16(13)\end{array}$ \\
\hline \multicolumn{4}{|c|}{ 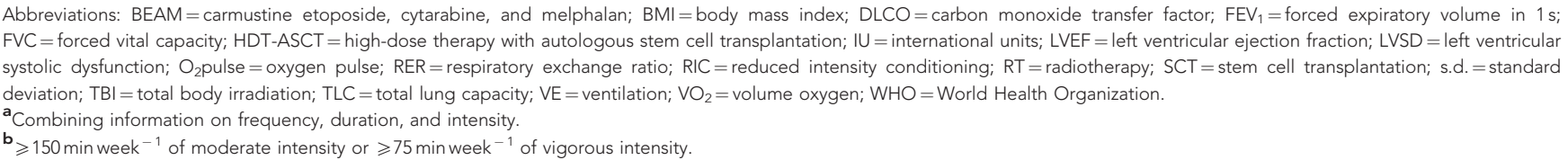 } \\
\hline
\end{tabular}

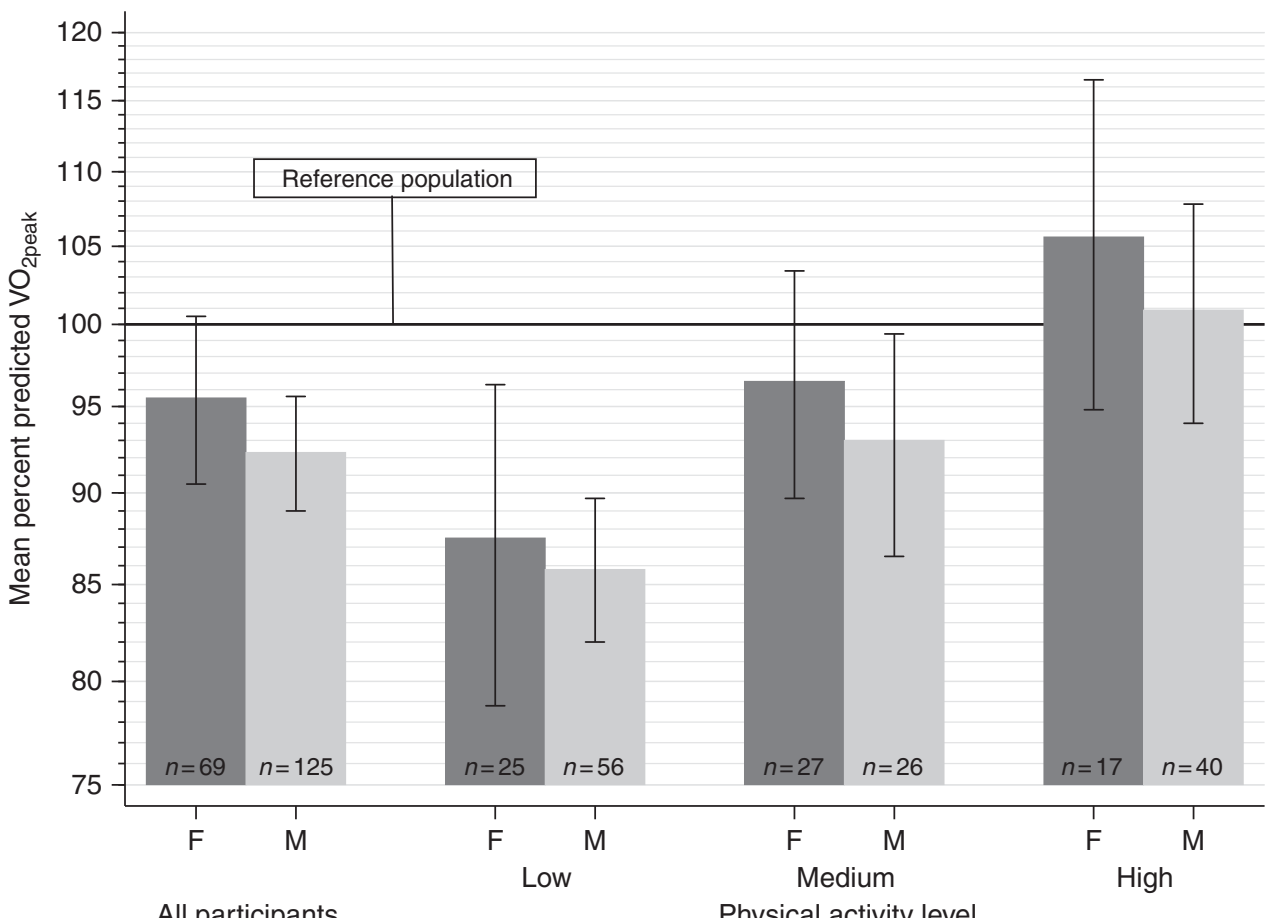

Figure 2. Mean peak oxygen uptake $\left(\mathrm{VO}_{2 \text { peak }}\right)$ with $95 \%$ confidence intervals among 194 lymphoma survivors after HDT-ASCT compared with sex- and age-predicted reference values from a sedentary general population (Fitzgerald and Wilson/Tanaka equations). Abbreviations: $\mathrm{F}=$ female; $\mathrm{M}=$ male.

dose was associated with decreasing $\mathrm{VO}_{2 \text { peak }}$ among the low active $\left(P_{\text {trend }}=0.01\right)$, while no such association was detected among the medium and highly active (Supplementary Table S1). Within the two highest doxorubicin dose groups $\left(300-399 \mathrm{mg} \mathrm{m}^{-2}\right.$ and $400-$ $775 \mathrm{mg} \mathrm{m}^{-2}$ ), significant differences in $\mathrm{VO}_{2 \text { peak }}$ were found between the high and low activity groups (Figure 3 ).

\section{DISCUSSION}

$\mathrm{VO}_{2 \text { peak }}$ among the LSs was on average $4.5 \%$ (women) and $7.7 \%$ (men) lower than age-sex predicted values from the healthy, sedentary reference population. Twenty percent of male and twenty-three percent of female LSs had impaired $\mathrm{VO}_{2 \text { peak }}$. Impaired diffusion capacity and current smoking were associated with a reduction in $\mathrm{VO}_{2 \text { peak }}$. LSs who reported high levels of physical activity did, however, reach the $\mathrm{VO}_{2 \text { peak }}$ level of the reference population. Further, a high physical activity level seemed to mitigate the inverse association between doxorubicin and $\mathrm{VO}_{2 \text { peak. }}$. In sum, these findings underline the importance of longterm monitoring of LSs after HDT-ASCT, and highlight a need for increased focus on physical activity counseling and smoking cessation in the clinical oncology setting.

After a mean follow-up of 10.2 years since HDT-ASCT, $53 \%$ of the LSs were not meeting the physical activity recommendations and $17 \%$ were current smokers. As both are modifiable factors, they call upon oncology care providers to encourage lifestyle change. Although oncologists hold powerful roles as lifestyle promoters, and may benefit from the so-called 'teachable moment' provided by the diagnosis itself (Demark-Wahnefried et al, 2005), cancer survivors are often fatigued and it has proven difficult to change from an inactive to an active lifestyle. A study in Norwegian cancer survivors reported that only $12 \%$ changed from inactive 
Table 2. Exercise behaviour by quartiles of peak oxygen uptake $\left(\mathrm{VO}_{2 \text { peak }}\right)$ and by impaired vs normal $\mathrm{VO}_{2 p e a k}$

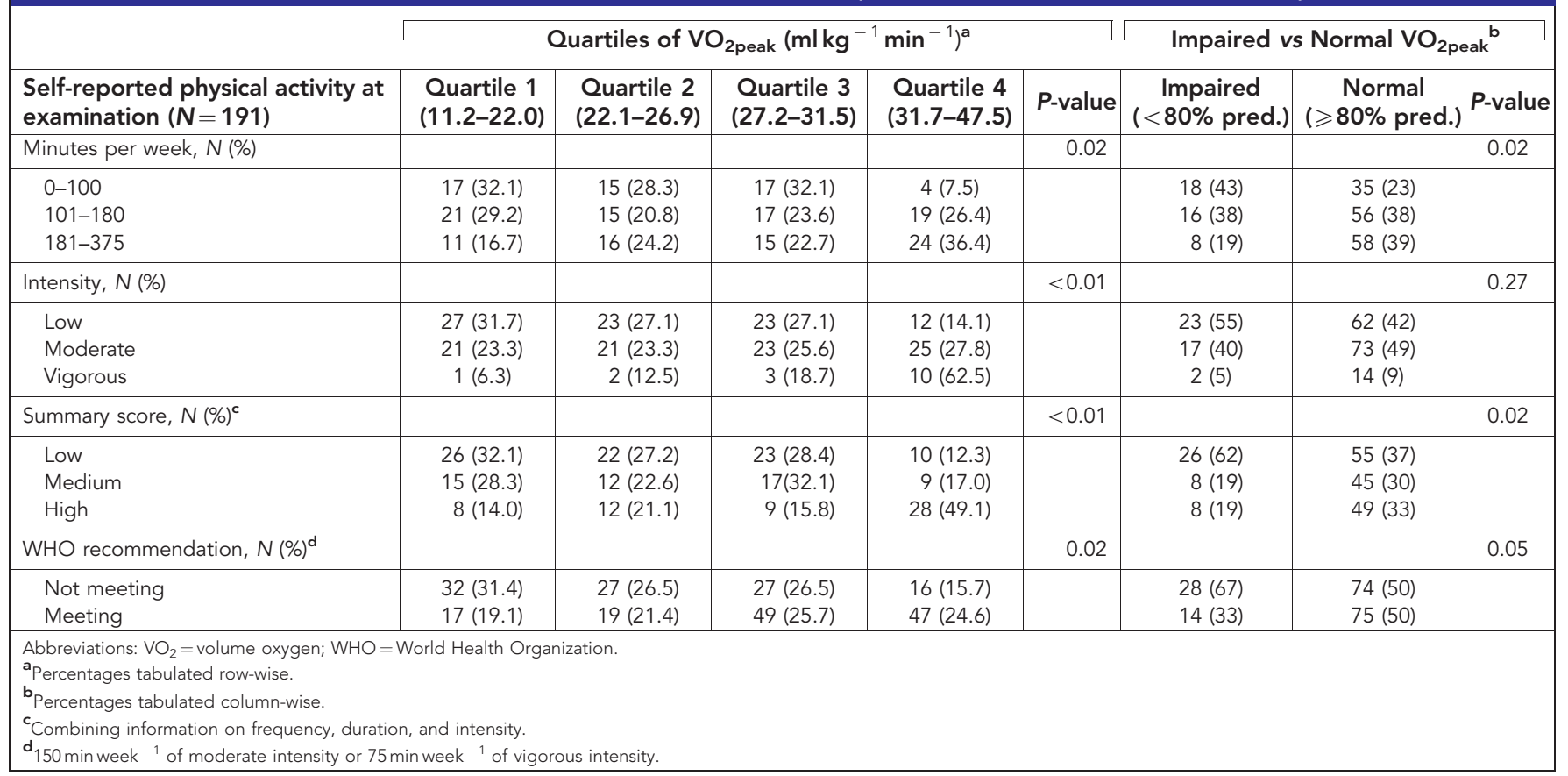

before diagnosis to active after treatment (Gjerset et al, 2011). Overweight, low educated, and smokers were associated with physical inactivity after treatment in the Gjerset et al (2011) study, and constitute subgroups that should receive more attention with respect to lifestyle counseling.

To our knowledge, only one other study has examined cardiorespiratory fitness in cancer survivors post HDT-ASCT (Tuchman et al, 2015). This study was, however, conducted in survivors of multiple myeloma, with a mean $\mathrm{VO}_{2 \text { peak }}$ of $17.5 \mathrm{ml} \mathrm{kg}^{-1} \mathrm{~min}^{-1}$ at the age of 60 years (Tuchman et al, 2015). Although both disease presentation and purpose/type of HDT-ASCT differ between multiple myeloma and lymphoma, we believe that the lower age and the exclusion of HF cases in the present study explain the $10 \mathrm{ml} \mathrm{kg}^{-1} \mathrm{~min}^{-1}$ higher mean $\mathrm{VO}_{2 \text { peak }}$. There has been published a study protocol of a planned multicentre exercise-intervention trial in lymphoma and multiple myeloma survivors after HDT-ASCT in the Netherlands (Persoon et al, 2010), but to our knowledge no analysis of cardiorespiratory fitness in LSs after HDT-ASCT has been reported to date.

Although only a modest reduction in mean $\mathrm{VO}_{2 \text { peak }}$ was observed between all patients and the reference population of healthy sedentary individuals, 43 in 194 patients had impaired $\mathrm{VO}_{2 \text { peak. }}$. The larger proportion reporting low physical activity among the impaired $v s$ the normal $\mathrm{VO}_{2 \text { peak }}$ groups $(62 \%$ vs $37 \%$, respectively) could explain the relatively high number of patients with impaired $\mathrm{VO}_{2 \text { peak. }}$. The increase in $\mathrm{VO}_{2 \text { peak }}$ across levels of physical activity seen $v s$ the reference population persisted in the internal comparison for all measures of exercise behaviour (i.e., minutes per week, intensity, summary score, and WHO recommendation). Further, in the multivariable prediction of $\mathrm{VO}_{2 \text { peak }}$ a significant trend across levels of physical activity was observed. The significant difference in $\mathrm{VO}_{2 \text { peak }}$ between high and low active LSs within the two highest doxorubicin dose groups suggests that a high physical activity level could mitigate the adverse effects of doxorubicin on $\mathrm{VO}_{2 \text { peak }}$. The inverse association between doxorubicin and $\mathrm{VO}_{2 \text { peak }}$ among low active might be ascribed to doxorubicin-induced impairments in endothelial function and change in $\mathrm{Ca}^{2+}$ response in the skeletal muscle
(Chow et al, 2006; van Norren et al, 2009), while increased capillarisation and mitochondrial density could explain why $\mathrm{VO}_{2 \text { peak }}$ was similar among highly active across doses of doxorubicin (Lakoski et al, 2012).

On the basis of the previously reported associations between chest RT and cardiopulmonary sequelae in LSs (Lund et al, 1996b; Adams et al, 2004; Murbraech et al, 2015), an inverse association between chest $\mathrm{RT}$ and $\mathrm{VO}_{2 \text { peak }}$ would have been plausible but was, however, not seen in our data. This might be explained by the fact that we studied adult LSs, excluding RT-induced organ development impairments typically seen in childhood cancer survivors (Huang et al, 2011), and that only 10 (5\%) patients received mantle field RT. The independent effect from current smoking on $\mathrm{VO}_{2 \text { peak }}$ is in line with results from non-cancer populations (Hirsch et al, 1985; Suminski et al, 2009).

Cardiorespiratory fitness depends on the lung's diffusion capacity, the heart's stroke volume, the blood's Hb concentration, the endothelial function, and the skeletal muscle's capillary density and number of mitochondria (Hoppeler and Weibel, 1998). In addition to HDT-ASCT, the LSs might have been through intensive treatment regimens with high cumulative doses of doxorubicin, bleomycin and for some radiotherapy, all in which have been associated with deteriorative effects on organ systems involved in the oxygen transport (Lund et al, 1996b; Chow et al, 2006; van Norren et al, 2009; Murbraech et al, 2015). To assess more precisely which organ components might have been damaged by such anticancer therapy, single-organ exams are necessary in addition to the collective assessment of $\mathrm{VO}_{2 \text { peak }}$ by cardiopulmonary exercise testing, and were recently highlighted as a need for future studies (Tuchman et al, 2015).

We performed echocardiography, pulmonary function testing, and blood sampling in order to dissect any single-organ impairments. As cardiac output is known to be the primary limiting factor for $\mathrm{VO}_{2 \text { peak }}$ (Basset and Howley, 2000), patients with HF were excluded. We only detected left ventricular systolic dysfunction in $7 \%$ of the participants, and no association was found between $\mathrm{LVEF}$ and $\mathrm{VO}_{2 \text { peak }}$ in the regression analysis. The pulmonary function tests revealed that $44 \%$ of our patients had impaired gas diffusion capacity, which accords with a recent study 
Table 3. Peak oxygen uptake $\left(\mathrm{VO}_{2 \text { peak }}\right)$, ventilation and workload associated with treatment exposures and other characteristics; presented as regression coefficients with $P$-values

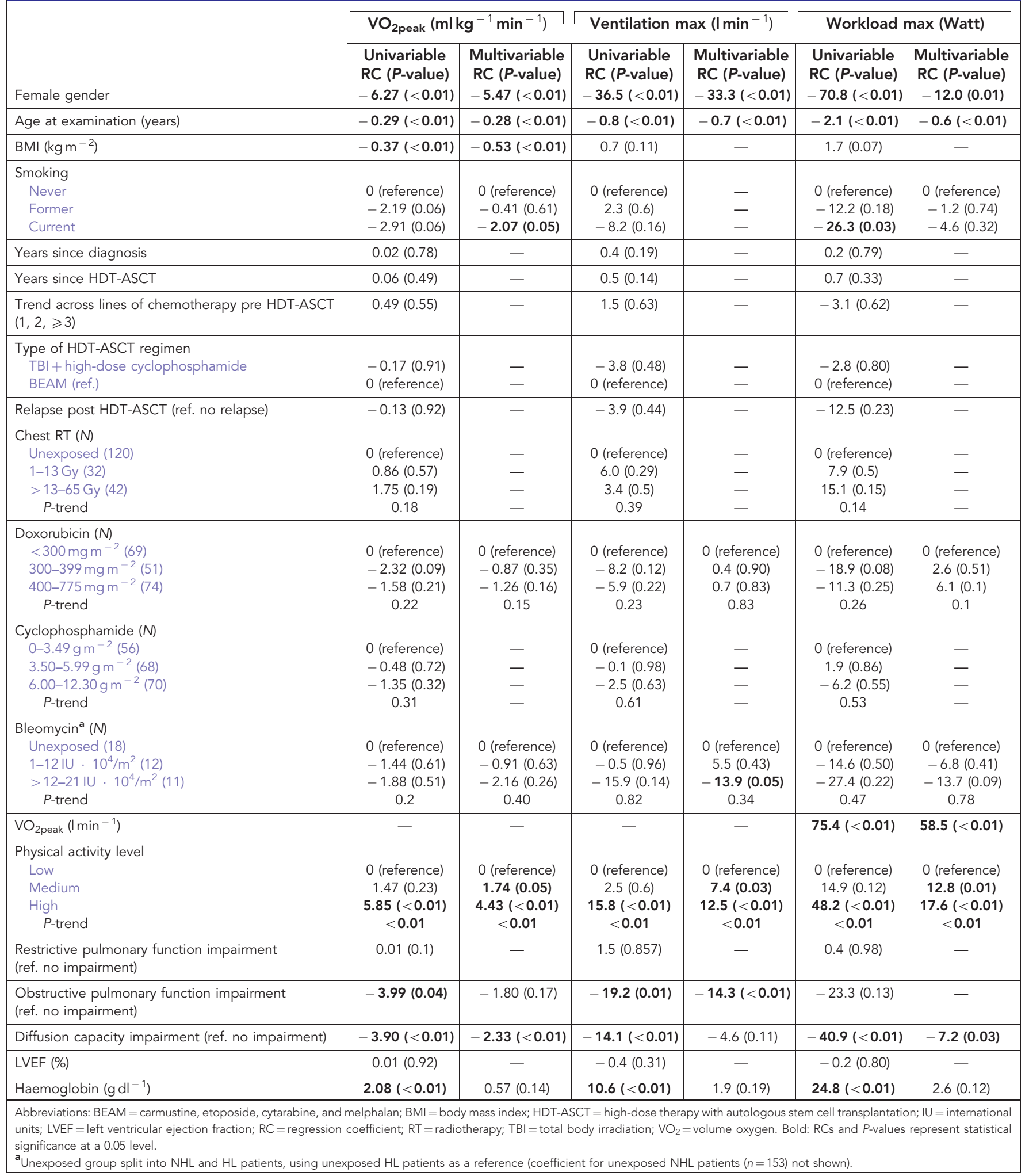

by Armenian et al (2015) on long-term pulmonary function in childhood cancer survivors, where impaired diffusion capacity (defined as $<75 \%$ predicted) was detected in $35 \%$ of the patients. Impaired gas diffusion capacity was independently associated with reduced $\mathrm{VO}_{2 \text { peak }}$ and workload in the regression analysis. Although, the diffusive capacity of the lung is oversized in terms of adequate oxygen saturation of the arterial blood in healthy individuals (Basset and Howley, 2000), our data showed that cardiorespiratory fitness among LSs without HF was indeed limited by impaired diffusion capacity. Although neither LVEF nor $\mathrm{Hb}$ concentration was independently associated with $\mathrm{VO}_{2 \text { peak }}$, we cannot rule out that these factors have contributed in conjunction 


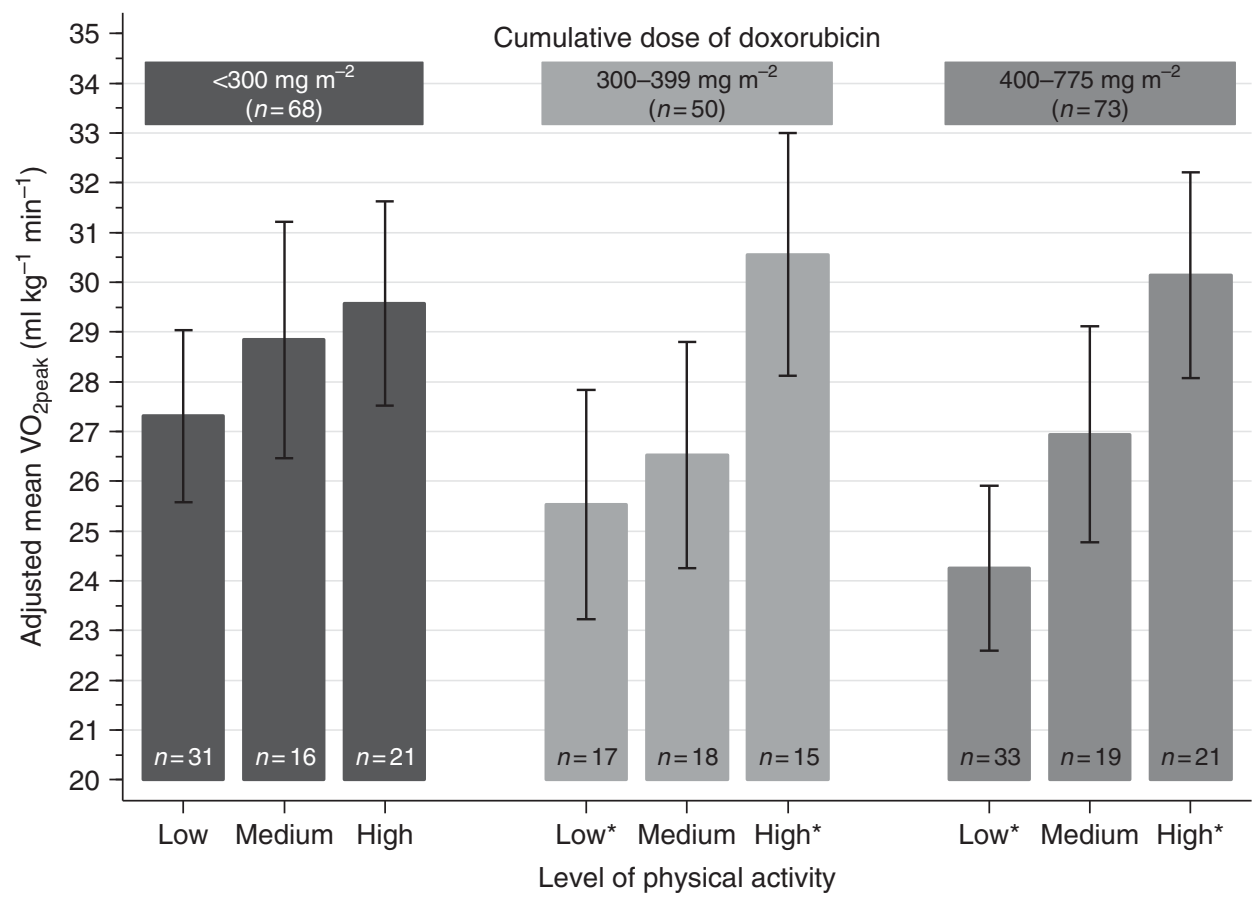

Figure 3. Mean peak oxygen uptake $\left(\mathrm{VO}_{2 \text { peak, }} \mathrm{ml} \mathrm{kg}^{-1} \mathrm{~min}^{-1}\right)$ with $95 \%$ confidence intervals $(\mathrm{Cls})$ by physical activity level (weighted sum of self-reported frequency, duration, and intensity) over groups of cumulative doxorubicin doses, adjusted for gender; age at survey (continuous); BMI (continuous); smoking (never, former, current); diffusion capacity (impaired, not impaired). Adjusted means were predicted by using Stata's post-estimation command 'margins' after linear regression. * Statistically significant difference between low and high physical activity level within doxorubicin group (i.e., non-overlapping $\mathrm{Cls}$ ).

with impaired diffusion capacity and collectively reduced cardiorespiratory fitness in our patients as compared with the reference population.

Strengths of the present study include the large study population of only LSs after HDT-ASCT, in which cardiorespiratory fitness has not been reported on previously, and further the high-quality data from hospital records, from thorough medical exams, and from a validated questionnaire on physical activity. Further, the participants did not differ from nonparticipants, which strengthen the external validity and the generalisability of our results.

Our study was, however, limited to a cross-sectional analysis as we lacked pre-diagnostic data, and could not identify causal factors of cardiorespiratory fitness. Survival and risk of death analyses according to cardiorespiratory fitness were yet not possible due to the short period of time since testing and examination, but are warranted and will further elucidate whether preservation of cardiorespiratory fitness may prolong survival and reduce mortality in LSs after HDT-ASCT.

In summary, our data suggest that highly physically active LSs after HDT-ASCT could counteract the adverse effects from intensive anticancer treatment and reach the $\mathrm{VO}_{2 \text { peak }}$ level of a sedentary, healthy reference population. Impaired diffusion capacity and current smoking were independent factors associated with decreasing $\mathrm{VO}_{2 \text { peak }}$. We therefore suggest increased attention towards physical activity counseling/interventions and smoking cessation advice in this patient group. Individuals with impaired diffusion capacity may benefit from subsequent monitoring to detect pulmonary vascular diseases.

\section{ACKNOWLEDGEMENTS}

We thank Unn-Merete Fagerli, MD PhD, and Torgeir Wethal, $\mathrm{MD} \mathrm{PhD}$, for their contribution in patient recruitment and clinical assessment at St Olavs University Hospital. We thank Ronnie Babigumira, MSc, and Linda Vos, PhD, at the Cancer Registry of Norway for advice on data management and statistics. The study was supported by South-Eastern Norway Regional Health Authority, and received no funding from the medical industry. LWJ is supported by grants from the US National Cancer Institute and AKTIV Against Cancer. $\mathrm{HH}$ is in part supported by a grant from the Norwegian Cancer Society.

\section{CONFLICT OF INTEREST}

The authors declare no conflict of interest.

\section{REFERENCES}

Adams MJ, Lipsitz SR, Colan SD, Tarbell NJ, Treves ST, Diller L, Greenbaum N, Mauch P, Lipshultz SE (2004) Cardiovascular status in long-term survivors of Hodgkin's disease treated with chest radiotherapy. J Clin Oncol 22(15): 3139-3148.

Armenian SH, Landier W, Francisco L, Herrera C, Mills G, Siyahian A, Supab N, Wilson K, Wolfson JA, Horak D, Bhatia S (2015) Long-term pulmonary function in survivors of childhood cancer. J Clin Oncol 33(14): 1592-1600.

American Thoracic Society; American College of Chest Physicians (2003) ATS/ACCP Statement on cardiopulmonary exercise testing. Am J Respir Crit Care Med 167(2): 211-277.

Bassett Jr DR, Howley ET (2000) Limiting factors for maximum oxygen uptake and determinants of endurance performance. Med Sci Sports Exerc 32(1): 70-84.

Bhatia S, Robison LL, Francisco L, Carter A, Liu Y, Grant M, Baker KS, Fung H, Gurney JG, McGlave PB, Nademanee A, Ramsay NK, Stein A, Weisdorf DJ, Forman SJ (2005) Late mortality in survivors of autologous hematopoietic-cell transplantation: report from the Bone Marrow Transplant Survivor Study. Blood 105(11): 4215-4222. 
Chow AY, Chin C, Dahl G, Rosenthal DN (2006) Anthracyclines cause endothelial injury in pediatric cancer patients: a pilot study. J Clin Oncol 24(6): 925-928.

Davies M, Hobbs F, Davis R, Kenkre J, Roalfe AK, Hare R, Wosornu D, Lancashire RJ (2001) Prevalence of left-ventricular systolic dysfunction and heart failure in the Echocardiographic Heart of England Screening study: a population based study. Lancet 358(9280): 439-444.

Demark-Wahnefried W, Aziz NM, Rowland JH, Pinto BM (2005) Riding the crest of the teachable moment: promoting long-term health after the diagnosis of cancer. J Clin Oncol 23(24): 5814-5830.

Fitzgerald MD, Tanaka H, Tran ZV, Seals DR (1997) Age-related declines in maximal aerobic capacity in regularly exercising $v s$ sedentary women: a meta-analysis. J Appl Physiol 83(1): 160-165.

Fulbright JM (2011) Review of cardiotoxicity in pediatric cancer patients: during and after therapy. Cardiol Res Pract 2011: 942090.

Gjerset GM, Fosså SD, Courneya KS, Skovlund E, Thorsen L (2011) Exercise behavior in cancer survivors and associated factors. J Cancer Surviv 5(1): 35-43.

Hirsch GL, Sue DY, Wasserman K, Robinson TE, Hansen JE (1985) Immediate effects of cigarette smoking on cardiorespiratory responses to exercise. J Appl Physiol 58(6): 1975-1981.

Hoppeler H, Weibel ER (1998) Limits for oxygen and substrate transport in mammals. J Exp Biol 201(Pt 8): 1051-1064.

Huang TT, Hudson MM, Stokes DC, Krasin MJ, Spunt SL, Ness KK (2011) Pulmonary outcomes in survivors of childhood cancer: a systematic review. Chest 140(4): 881-901.

Hunt SA, Abraham WT, Chin MH, Feldman AM, Francis GS, Ganiats TG, Jessup M, Konstam MA, Mancini DM, Michl K, Oates JA, Rahko PS, Silver MA, Stevenson LW, Yancy CW (2009) 2009 focused update incorporated into the ACC/AHA 2005 Guidelines for the Diagnosis and Management of Heart Failure in Adults: a report of the American College of Cardiology Foundation/American Heart Association Task Force on Practice Guidelines: developed in collaboration with the International Society for Heart and Lung Transplantation. Circulation 119(14): e391-e479.

Jones LW, Eves ND, Haykowsky M, Freedland SJ, Mackey JR (2009) Exercise intolerance in cancer and the role of exercise therapy to reverse dysfunction. Lancet Oncol 10(6): 598-605.

Jones LW, Eves ND, Haykowsky M, Joy AA, Douglas PS (2008) Cardiorespiratory exercise testing in clinical oncology research: systematic review and practice recommendations. Lancet Oncol 9(8): 757-765.

Jones LW, Friedman AH, West MJ, Mabe SK, Fraser J, Kraus WE, Friedman HS, Tresch MI, Major N, Reardon DA (2010) Quantitative assessment of cardiorespiratory fitness, skeletal muscle function, and body composition in adults with primary malignant glioma. Cancer 116(3): 695-704.

Jones LW, Liu Q, Armstrong GT, Ness KK, Yasui Y, Devine K, Tonorezos E, Soares-Miranda L, Sklar CA, Douglas PS, Robison LL, Oeffinger KC (2014) Exercise and risk of major cardiovascular events in adult survivors of childhood hodgkin lymphoma: a report from the childhood cancer survivor study. J Clin Oncol 32(32): 3643-3650.

Kurtze N, Rangul V, Hustvedt BE, Flanders WD (2008) Reliability and validity of self-reported physical activity in the Nord-Trøndelag Health Study: HUNT 1. Scand J Public Health 36(1): 52-61.

Lang RM, Bierig M, Devereux RB, Flachskampf FA, Foster E, Pellikka PA, Picard MH, Roman MJ, Seward J, Shanewise JS, Solomon SD, Spencer KT, Sutton MS, Stewart WJ. Chamber Quantification Writing Group; American Society of Echocardiography's Guidelines and Standards Committee; European Association of Echocardiography (2005) Recommendations for chamber quantification: a report from the American Society of Echocardiography's Guidelines and Standards Committee and the Chamber Quantification Writing Group, developed in conjunction with the European Association of Echocardiography, a branch of the European Society of Cardiology. J Am Soc Echocardiogr 18(12): $1440-1463$.

Lakoski SG, Eves ND, Douglas PS, Jones LW (2012) Exercise rehabilitation in patients with cancer. Nat Rev Clin Oncol 9(5): 288-296.

Lakoski SG, Willis BL, Barlow CE, Leonard D, Gao A, Radford NB, Farrell SW, Douglas PS, Berry JD, DeFina LF, Jones LW (2015) Midlife cardiorespiratory fitness, incident cancer, and survival after cancer in men: The Cooper Center Longitudinal Study. JAMA Oncol 1(2): 231-237.

Linch DC, Winfield D, Goldstone AH, Moir D, Hancock B, McMillan A, Chopra R, Milligan D, Hudson GV (1993) Dose intensification with autologous bone-marrow transplantation in relapsed and resistant Hodgkin's disease: results of a BNLI randomised trial. Lancet 341(8852): 1051-1054.

Lund MB, Ihlen H, Voss BM, Abrahamsen AF, Nome O, Kongerud J, Stugaard M, Forfang K (1996a) Increased risk of heart valve regurgitation after mediastinal radiation for Hodgkin's disease: an echocardiographic study. Heart 75(6): 591-595.

Lund MB, Kongerud J, Boe J, Nome O, Abrahamsen AF, Ihlen H, Forfang K (1996b) Cardiopulmonary sequelae after treatment for Hodgkin's disease: increased risk in females? Ann Oncol 7(2): 257-264.

Macintyre N, Crapo RO, Viegi G, Johnson DC, van der Grinten CP, Brusasco V, Burgos F, Casaburi R, Coates A, Enright P, Gustafsson P, Hankinson J, Jensen R, McKay R, Miller MR, Navajas D, Pedersen OF, Pellegrino R, Wanger J (2005) Standardisation of the single-breath determination of carbon monoxide uptake in the lung. Eur Respir J 26(4): 720-735.

Miller MR, Hankinson J, Brusasco V, Burgos F, Casaburi R, Coates A, Crapo R, Enright P, van der Grinten CP, Gustafsson P, Jensen R, Johnson DC, MacIntyre N, McKay R, Navajas D, Pedersen OF, Pellegrino R, Viegi G, Wanger J. ATS/ERS Task Force (2005) Standardisation of spirometry. Eur Respir J 26(2): 319-338.

Mitchell MN (2012) Interpreting and Visualizing Regression Models Using Stata. Stata Press: TX, USA, pp 26-29.

Murbraech K, Smeland KB, Holte H, Loge JH, Lund MB, Wethal T, Holte E, Rösner A, Dalen H, Kvaløy S, Falk RS, Aakhus S, Kiserud CE (2015) Heart failure and asymptomatic left ventricular systolic dysfunction in lymphoma survivors treated with autologous stem-cell transplantation: A National Cross-Sectional Study. J Clin Oncol 33(24): 2683-2691.

Nilsen TI, Romundstad PR, Petersen H, Gunnell D, Vatten LJ (2008) Recreational physical activity and cancer risk in subsites of the colon (the Nord-Trøndelag Health Study). Cancer Epidemiol Biomarkers Prev 17(1): 183-188.

Persoon S, Kersten MJ, Chinapaw MJ, Buffart LM, Burghout H, Schep G, Brug J, Nollet F (2010) Design of the EXercise Intervention after Stem cell Transplantation (EXIST) study: a randomized controlled trial to evaluate the effectiveness and cost-effectiveness of an individualized high intensity physical exercise program on fitness and fatigue in patients with multiple myeloma or (non-) Hodgkin's lymphoma treated with high dose chemotherapy and autologous stem cell transplantation. BMC Cancer 10: 671.

Quanjer PH, Tammeling GJ, Cotes JE, Pedersen OF, Peslin R, Yernault JC (1993) Lung volumes and forced ventilatory flows. Report working party standardization of lung function tests, European community for steel and coal. Official statement of the European respiratory society. Eur Respir $J$ Suppl 16: 5-40.

Rodgers 3rd GM, Becker PS, Bennett CL, Cella D, Chanan-Khan A, Chesney C, Cleeland C, Coccia PF, Djulbegovic B, Garst JL, Gilreath JA, Kraut EH, Lin WC, Matulonis U, Millenson M, Reinke D, Rosenthal J, Sabbatini P, Schwartz RN, Stein RS, Vij R. National Comprehensive Cancer Network (2008) Cancer- and chemotherapy induced anemia. J Natl Compr Canc Netw 6(6): 536-564.

Schmitz N, Linch DC, Dreger P, Goldstone AH, Boogaerts MA, Ferrant A, Demuynck HM, Link H, Zander A, Barge A (1996) Randomised trial of filgrastim-mobilised peripheral blood progenitor cell transplantation versus autologous bone-marrow transplantation in lymphoma patients. Lancet 347(8998): 353-357.

Schmitz N, Pfistner B, Sextro M, Sieber M, Carella AM, Haenel M, Boissevain F, Zschaber R, Müller P, Kirchner H, Lohri A, Decker S, Koch B, Hasenclever D, Goldstone AH, Diehl V. German Hodgkin's Lymphoma Study Group; Lymphoma Working Party of the European Group for Blood and Marrow Transplantation (2002) Aggressive conventional chemotherapy compared with high-dose chemotherapy with autologous haemopoietic stem-cell transplantation for relapsed chemosensitive Hodgkin's disease: a randomised trial. Lancet 359(9323): 2065-2071.

Smeland KB, Kiserud CE, Lauritzsen GF, Blystad AK, Fagerli UM, Fluge $\varnothing$, Fosså A, Hammerstrøm J, Kolstad A, Loge JH, Maisenhølder M, Østenstad B, Kvaløy S, Holte H (2013a) High-dose therapy with autologous stem cell support for lymphoma in Norway 1987-2008. Tidsskr Nor Laegeforen 133(16): 1704-1709.

Smeland KB, Kiserud CE, Lauritzsen GF, Fagerli UM, Falk RS, Fluge $\varnothing$, Fosså A, Kolstad A, Loge JH, Maisenhölder M, Kvaløy S, Holte H (2015) Conditional survival and excess mortality after high-dose therapy with autologous stem cell transplantation for adult refractory or relapsed Hodgkin lymphoma in Norway. Haematologica 100(6): e240-e243. 
Smeland KB, Kiserud CE, Lauritzsen GF, Fosså A, Hammerstrøm J, Jetne V, Kolstad A, Kvalheim G, Loge JH, Løkeland T, Tangen JM, Holte H, Kvaløy S (2013b) High-dose therapy with autologous stem cell support for lymphoma-from experimental to standard treatment. Tidsskr Nor Laegeforen 133(16): 1735-1739.

Suminski RR, Wier LT, Poston W, Arenare B, Randles A, Jackson AS (2009) The effect of habitual smoking on measured and predicted VO2(max). $J$ Phys Act Health 6(5): 667-673.

Tuchman SA, Lane A, Hornsby WE, Bishop C, Thomas S, Herndon 2nd JE, Long G, Gasparetto C, Jones LW (2015) Quantitative measures of physical functioning after autologous hematopoietic stem cell transplantation in multiple myeloma: a feasibility study. Clin Lymphoma Myeloma Leuk 15(2): 103-109.

Vanderwalde AM, Sun CL, Laddaran L, Francisco L, Armenian S, Berano-Teh J, Wong FL, Popplewell L, Somlo G, Stein AS, Nademanee A, Krishnan A, Kogut N, Forman SJ, Bhatia S (2013) Conditional survival and cause-specific mortality after autologous hematopoietic cell transplantation for hematological malignancies. Leukemia 27(5): 1139-1145. van Norren K, van Helvoort A, Argilés JM, van Tuijl S, Arts K, Gorselink M, Laviano A, Kegler D, Haagsman HP, van der Beek EM (2009) Direct effects of doxorubicin on skeletal muscle contribute to fatigue. Br J Cancer 100(2): 311-314.

Wanger J, Clausen JL, Coates A, Pedersen OF, Brusasco V, Burgos F, Casaburi R, Crapo R, Enright P, van der Grinten CP, Gustafsson P, Hankinson J, Jensen R, Johnson D, Macintyre N, McKay R, Miller MR, Navajas D, Pellegrino R, Viegi G (2005) Standardisation of the measurement of lung volumes. Eur Respir J 26(3): 511-522.

Wilson TM, Tanaka H (2000) Meta-analysis of the age-associated decline inmaximal aerobic capacity in men: relation to training status. Am J Physiol Heart Circ Physiol 278(3): H829-H834.

This work is published under the standard license to publish agreement. After 12 months the work will become freely available and the license terms will switch to a Creative Commons AttributionNonCommercial-Share Alike 4.0 Unported License.

Supplementary Information accompanies this paper on British Journal of Cancer website (http://www.nature.com/bjc) 